\title{
The Impact of Deer Herbivory and Drought on Population Growth of Goodyera pubescens (Orchidaceae) in Southwestern Quebec
}

\author{
Joyce M. RedDOCH and Allan H. RedDOCH
}

548 Rivershore Crescent, Gloucester, Ontario K1J 7Y7 Canada; email: reddoch@magma.ca

Reddoch, Joyce M., and Allan H. Reddoch. 2012. The impact of deer herbivory and drought on population growth of Goodyera pubescens (Orchidaceae) in southwestern Quebec. Canadian Field-Naturalist 126(3): 242-244.

During the last decade of a 37-year study of Downy Rattlesnake-plaintain (Goodyera pubescens (Willdenow) R. Brown) major herbivory by White-tailed Deer (Odocoileus virginianus) caused marked decreases in the sizes of two previously expanding populations. The 2012 drought resulted in an additional decline of one population. Because population growth depends on large flowerings, which occur only every four to eight years, recovery to 2002 levels would take several decades under favourable conditions.

Key Words: Downy Rattlesnake-plantain, Goodyera pubescens, long-term studies, population growth, climate, herbivory, Whitetailed Deer, Odocoileus virginianus, 2012 drought, Gatineau Park, Quebec.

In 2007 we published the results of our 31-year (1976-2006) study of two populations of Goodyera pubescens (Willdenow) R. Brown in Gatineau Park in southwestern Quebec (Reddoch and Reddoch 2007). Here we provide a six-year update on the impact and implications of deer herbivory and drought on these two populations.

In Gatineau Park, near the northern edge of its distribution (Kallunki 2002), Goodyera pubescens is an orchid of mature woodlands. It is a clonal species that consists of unbranched, leafy rhizomes that extend along the soil surface, anchored by occasional shallow roots. The leaves along the rhizome and around the growing tip give the appearance of an elongated rosette.

At the Gatineau Park study sites, each rosette (ramet) flowers only once, after developing for four to eight years. After flowering, one to three offshoots emerge near the base of the flowering stem, and the parent rhizome slowly dies. These offshoots, which are the next generation of rosettes, repeat the same cycle of growth as the parent (Reddoch and Reddoch 2007).

Seedlings also contribute to population growth but on a much longer time scale than vegetative reproduction. Few seedlings survive to flower and they require many years to do so (Reddoch and Reddoch 2007). The longest surviving seedling of eight that we have followed, which appeared in 1998, still has not flowered after 15 years. The other two surviving seedlings, which appeared in 2004, also have not yet flowered. It has been observed in Massachusetts (Ames 1921, 1922) and Quebec (Reddoch and Reddoch 2007) that seedlings often originate close to rhizomes. When young, seedlings can readily be distinguished from offshoots by their small, delicate appearance, but as they develop, they come to resemble offshoots. Thus, anyone looking at a patch for the first time will not be able to distinguish maturing seedlings from offshoots and might mistakenly conclude that there are branched rhizomes.

Flowering of mature rosettes is usually initiated by a dry period in the May of the year preceding flowering, perhaps combined with other conditions. Such dry periods of below average precipitation and above average temperature last at least 19 days. These dry periods, which occur only every several years, are followed the next year by synchronous large-flowering of Goodyera pubescens populations (8\% to $30 \%$ of the rosettes; Reddoch and Reddoch 2007). In the last decade there have been large flowerings in 2002 and 2006.

White-tailed Deer (Odocoileus virginianus) eat rosettes and inflorescences, killing rosettes and eliminating seed sources. From the mid-1970s until 2002, both study populations increased exponentially (Figures 1 and 2). We deduced that the Champlain Lookout population increased faster than the Moorside population because the former population had experienced no deer herbivory during that period while some deer herbivory had been evident since the mid-1980s in the latter population (Reddoch and Reddoch 2007).

Our recent observations show that in the Champlain Lookout population, which was a single patch $165 \mathrm{~cm}$ $\times 100 \mathrm{~cm}$, major deer browsing reduced the number of rosettes from a high of 191 in 2002 to less than a quarter of that number by 2009 (Figure 1). Because we saw at least one deer close to the patch on almost every visit, we placed a large tree branch across the remaining rosettes in 2009. Since then, rosette numbers have remained constant. The Moorside population consisted of 10 patches scattered over a half kilometre. It numbered 867 rosettes in 2002, dropped to $65 \%$ of that number by 2004 and remained relatively stable until 2011 (Figure 2).

Between about 1995 and 2005, the herbaceous and shrub layers in the study areas essentially disappeared 


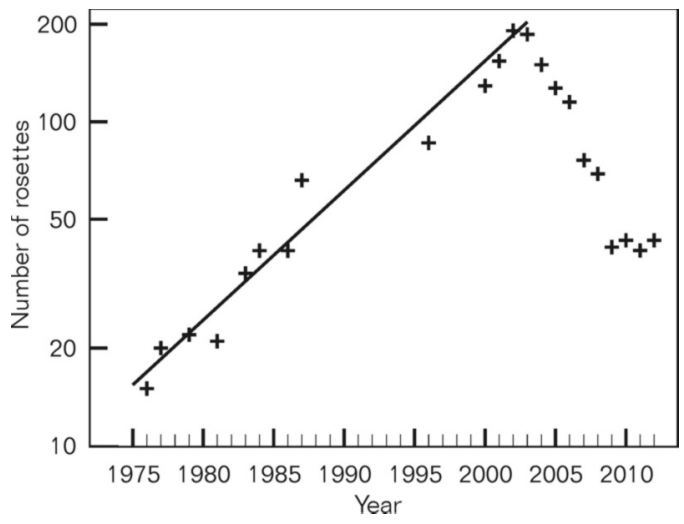

FIGURE 1. Growth curve of the Champlain Lookout population (1976-2002), subsequent decline (2003-2008), and levelling off (2009-2012); semi-log plot with fitted line for period of exponential growth.

leaving wide-open vistas through the forest. This observation is consistent with the changing densities of White-tailed Deer over the study period. Between 1980 and 1989, deer density in Gatineau Park increased to $5.5 \mathrm{deer} / \mathrm{km}^{2}$ (Dryade $1991 *$ ). Five deer per $\mathrm{km}^{2}$ is considered the upper limit before deer herbivory causes serious and perhaps irreversible damage to the forest herbaceous layer (Anderson 1994, Whigham 2004, McGraw and Furedi 2005). After 2002 both orchid populations declined as deer densities increased. In 2004/2005 deer density had reached $15.6 \mathrm{deer} / \mathrm{km}^{2}$ (Tecsult Inc. 2005*). After the exceptionally severe winter in 2007/2008, deer density dropped to 5 deer per $\mathrm{km}^{2}$ by 2011 (personal communication, Quebec Ministry of Natural Resources and Wildlife). The tree branch further protected the Champlain Lookout population from deer access.

The severe summer drought in 2012 (Environment Canada 2012*) affected the Moorside population markedly (Figure 2), causing the leaves and rhizomes of many rosettes in areas of thin soil to die. No rosettes died in the Champlain Lookout population. That population was apparently more protected from drought, likely because it was situated on deeper soil near the base of a north-facing slope of a small, moist valley.

The growth of a Goodyera pubescens population depends on flowering, both to initiate vegetative reproduction by offshoots and for seed production. Flowering in relatively large numbers can take place only every several years following extensive warm, dry periods in the previous May and only by mature rosettes. Further, for population growth to occur, flowering rosettes must produce at least two offshoots, one to replace the parent rosette, which dies after flowering and reproduction, and at least one additional offshoot to contribute to the expansion of the population. When deer herbivory

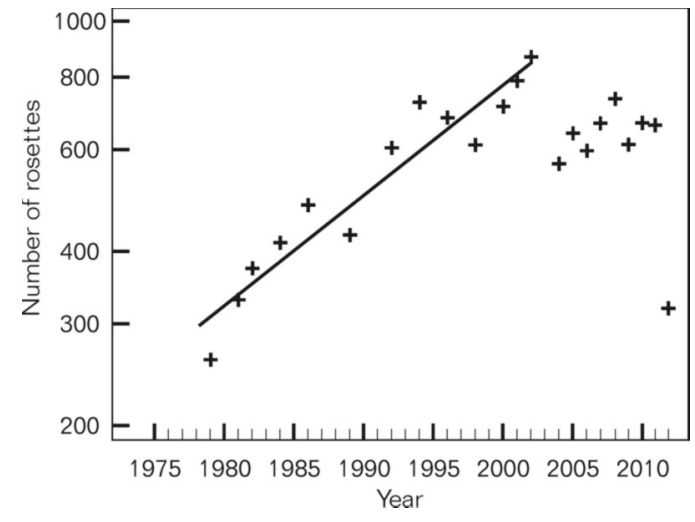

FIGURE 2. Growth curve of the Moorside population (19782002), subsequent decline and stabilization (20032011); further decline in 2012 in response to the extreme summer drought; semi-log plot with fitted line for period of exponential growth.

removes rosettes from the populations, significant population recovery begins only after the above conditions are fulfilled.

Recovery of these populations to 2002 levels, in the absence of further herbivory and drought, would take several decades. The mechanism of recovery depends on sporadic climate-dependent initiation of flowering, as well as continued production of more than one offshoot per flowering rosette, in addition to on-going seed production, and other factors such as the continued health of the associated mycorrhizal fungi.

\section{Acknowledgements}

We thank the reviewers for their useful comments and the National Capital Commission for granting research permits to conduct this long-term study.

Documents Cited (marked * in text)

Dryade. 1991. Cerf de Virginie dans le parc de la Gatineau / Évaluation de la population et capacité de support du milieu. Commisssion de la capitale nationale, Ottawa, Ontario. 30 pages + appendices.

Environment Canada. 2012. National Climate Data and Information Archive, Environment Canada. Accessed 31 August 2012. www.climate.weatheroffice.gc.ca.

Tecsult Inc. 2005. Évaluation de la capacité de support du parc de la Gatineau pour le cerf de Virginie. Commission de la capitale nationale, Ottawa Ontario. 64 pages + appendices.

\section{Literature Cited}

Ames, O. 1921. Seed dispersal in relation to colony formation in Goodyera pubescens. Orchid Review 29: 105-107.

Ames, O. 1922. Notes on New England orchids,-II. The mycorrhiza of Goodyera pubescens. Rhodora 24: 37-46.

Anderson, R. C. 1994. Height of white-flowered trillium (Trillium grandiflorum) as an index of deer browsing intensity. Ecological Applications 4: 104-109. 
Kallunki, J. A. 2002. Goodyera pubescens in Flora of North America North of Mexico. Volume 26. Edited by Flora of North America Editorial Committee. Oxford University Press, New York, New York.

McGraw, J. B., and M. A. Furedi. 2005. Deer browsing and population viability of a forest understory plant. Science 307: 920-922.
Reddoch, J. M., and A. H. Reddoch. 2007. Population dynamics and flowering synchrony of Goodyera pubescens (Orchidaceae) in southwestern Quebec, Canada. Journal of the Torrey Botanical Society 134: 379-388.

Whigham, D. F. 2004. Ecology of woodland herbs in temperate deciduous forests. Annual Review of Ecology, Evolution, and Systematics 35: 583-621.

Received 12 October 2012

Accepted 8 November 2012 